\title{
PENYEBARAN JENIS PUSPA (Schima wallichii (DC.) Korth) DI RESORT KAWAH RATU, TAMAN NASIONAL GUNUNG HALIMUN SALAK, JAWA BARAT
}

\author{
Distribution of Puspa (Schima wallichii (DC.) Korth.) in Kawah Ratu Resort, \\ Gunung Halimun Salak National Park, West Java
}

\author{
Iwan Hilwan $^{1 *}$ dan Savira Nurul Aulia Rahman ${ }^{2}$
}

(Diterima 20 April 2021 /Disetujui 7 Juli 2021)

\begin{abstract}
Puspa (Schima wallichii (DC.) Korth.) is a type of plant that dominates the area of Gunung Halimun Salak National Park, especially at Kawah Ratu Resort. Puspa type is one of the upland plant species that can grow in critical land. The objective of this study is to identify the distribution pattern and the potential for regeneration of puspa species (Schima wallichii (DC.) Korth.) at Kawah Ratu Resort, Gunung Halimun Salak National Park, West Java. Data were collected by analyzing vegetation with a single plot method covering an area of 1 hectare at each location. The research was conducted in the Pamengpeuk Block and the Leles Block. The species found in the two research locations were 98 species. The results showed that the distribution pattern of puspa was clustered, both in the Pamengpeuk block and in the Leles block. A clustered spread indicates good youth growth. The ability of puspa regeneration in both locations was quite good because the number of puspa regeneration individuals was more than the individual trees.
\end{abstract}

Keywords: distribution, Gunung Halimun Salak National Park, Kawah Ratu Resort,puspa, Schima wallichii

\begin{abstract}
ABSTRAK
Puspa (Schima wallichii (DC.) Korth.) merupakan jenis tumbuhan yang mendominasi di kawasan Taman Nasional Gunung Halimun Salak terutama di Resort Kawah Ratu. Jenis puspa termasuk salah satu jenis tumbuhan dataran tinggi yang dapat tumbuh di lahan kritis. Tujuan penelitian ini adalah untuk mengidentifikasi pola penyebaran dan potensi permudaan jenis puspa (Schima wallichii (DC.) Korth.) di Resort Kawah Ratu, Taman Nasional Gunung Halimun Salak, Jawa Barat. Pengambilan data dilakukan dengan analisis vegetasi dengan metode petak tunggal seluas 1 ha pada setiap lokasi. Penelitian dilakukan di Blok Pamengpeuk dan Blok Leles. Jenis yang ditemukan pada kedua lokasi penelitian sebanyak 98 jenis. Hasil penelitian menunjukkan pola penyebaran puspa (Schima wallichii (DC.) Korth.) adalah mengelompok, baik di Blok Pamengpeuk maupun di Blok Leles. Penyebaran mengelompok menandakan adanya pertumbuhan permudaan yang baik. Kemampuan regenerasi puspa di kedua lokasi tergolong baik karena jumlah individu permudaan puspa lebih banyak dari pada individu pohonnya..
\end{abstract}

Kata kunci: pola penyebaran, Puspa, Resort Kawah Ratu, Schima wallichii, Taman Nasional Gunung Halimun Salak

\footnotetext{
${ }^{1}$ Dosen Departemen Silvikultur, Fakultas Kehutanandan Lingkungan, IPB University

* Penulis korespondensi:

e-mail: ihilwan@yahoo.co.id

${ }^{2}$ Mahasiswa Departemen Silvikultur, Fakultas Kehutanandan Lingkungan, IPB University
} 


\section{PENDAHULUAN}

Hutan pegunungan atau biasa disebut hutan montana merupakan salah satu hutan tropika basah yang tumbuh dan berkembang di wilayah pegunungan. Steenis (1950) dalam Mulyana (2015) membagi hutan pegunungan di Indonesia berdasarkan ketinggiannya, yaitu hutan tropika subalpine (3000-3350 mdpl), hutan hujan tropika pegunungan tinggi (1500-3000 mdpl), dan hutan hujan tropika pegunungan rendah atau bawah (1200-1500 mdpl). Resort Kawah Ratu, Taman Nasional Gunung Halimun Salak termasuk salah satu hutan hujan tropika pegunungan bawah.

Kawasan Taman Nasional Gunung Halimun Salak termasuk dalam klasifikasi hutan pegunungan tropis yang paling luas di Pulau Jawa, Prasetyo (2008) mengemukakan bahwa tutupan hutannya mencapai sekitar 60.000 ha. Kawasan ini memiliki beberapa fungsi diantaranya dalam penyimpanan keanekaragaman hayati, pengatur tata air, pendidikan, penelitian, sumber plasma nutfah, pengembangan budidaya, rekreasi, dan parawisata (Alhamd dan Polosakan 2011). Puspa (Schima wallichii), Rasamala (Altingia excelsa), Saninten (Castanopsis javanica), dan Pasang (Quercus gemeliflora) merupakan beberapa jenis yang mendominasi di Taman Nasional Gunung Halimun Salak (GHSNPMP-JICA 2007).

Puspa (Schima wallichii (DC.) Korth.) menurut Alhamd dan Polosakan (2011) adalah jenis tumbuhan yang tergolong famili Theaceae yang mendominasi di kawasan Taman Nasional Gunung Halimun Salak. Puspa juga termasuk salah satu jenis tumbuhan dataran tinggi yang dapat tumbuh di lahan kritis, sehingga mampu merestorasi hutan pegunungan yang rusak oleh kegiatan seperti pertambangan dan perambahan (Setyawan 2000). Penyebaran jenis puspa di Indonesia menyebar di sebagian pulau Sumatera, Kalimantan Tengah, Kalimantan Selatan, Kalimantan Timur dan juga di seluruh pulau Jawa (Buharman et al. 2011). Bloembergen (1952) dalam Aprianti (2013) menyebutkan penyebaran secara alami jenis puspa di Indonesia terdapat di Pulau Jawa, khususnya Jawa Barat pada ketinggian 1000-1500 mdpl. Tumbuhan ini tumbuh berkelompok membentuk hutan primer maupun sekunder.

Penelitian pola sebaran jenis puspa ini sangat penting diketahui untuk menambah pengetahuan lebih lanjut untuk meningkatkan pengelolaan Kawasan Taman Nasional Gunung Halimun Salak khususnya Resort Kawah Ratu. Penelitian ini bertujuan untuk mengidentifikasi pola penyebaran dan potensi permudaan jenis puspa (S. wallichii) di Resort Kawah

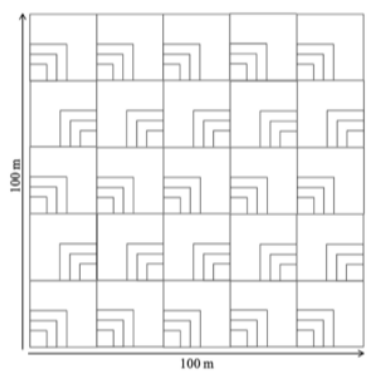

Gambar 1 Petak ukur pengamatan 1 ha
Ratu, Taman Nasional Gunung Halimun Salak, Jawa Barat. Penelitian ini diharapkan dapat memberikan informasi mengenai pola sebaran dan potensi permudaan jenis puspa (S. wallichii) serta sebagai acuan pengelolaan Resort Kawah Ratu, Kawasan Taman Nasional Gunung Halimun Salak, Jawa Barat.

\section{METODE PENELITIAN}

\section{Waktu dan Tempat Penelitian}

Penelitian dilakukan pada bulan Januari hingga bulan Maret 2021 di Resort Kawah Ratu, Taman Nasional Gunung Halimun Salak, Jawa Barat.

\section{Alat dan Bahan}

Alat yang digunakan dalam penelitian ini adalah Global positioning system (GPS), perlengkapan alat tulis, tally sheet, pita ukur, meteran jahit, suunto clinometer, haga hypsometer, kamera handphone, dan aplikasi perangkat lunak yaitu Ms. Word, Ms. Excel dan SexI-FS. Bahan atau objek yang diamati dalam penelitian ini adalah tegakan hutan khususnya puspa ( $S$. wallichii) yang berada dalam plot pengamatan hutan pegunungan Resort Kawah Ratu, Taman Nasional Gunung Halimun Salak, Jawa Barat.

\section{Prosedur Kerja}

\section{Tahap Persiapan}

Tahap persiapan meliputi beberapa kegiatan diantaranya, survei lokasi penelitian, perizinan lokasi penelitian, persiapan alat dan bahan yang digunakan untuk pengambilan data di lapangan.

\section{Penentuan Petak Contoh}

Pengamatan data lapangan dilakukan analisis vegetasi dengan metode petak tunggal berukuran $100 \mathrm{~m}$ x $100 \mathrm{~m}$. Menurut Wyatt-Smith (1959) dalam Soerianegara dan Indrawan (2005) ukuran petak contoh dengan luasan 0,6 ha sudah cukup mewakili suatu lahan. Petak pengamatan diletakkan pada Blok Pamengpeuk dan Blok Leles masing-masing seluas 1 ha. Petak pengamatan tersebut selanjutnya dibagi menjadi sub-plot

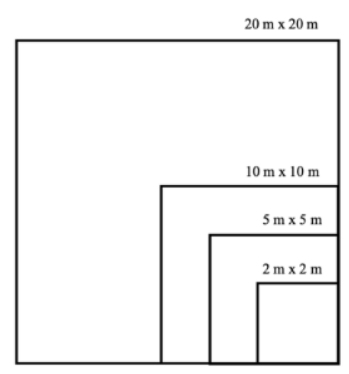

Keterangan:

Petak pengamatan ukuran $20 \mathrm{~m}$ x $20 \mathrm{~m}$ untuk pengamatan tingkat pohon, $10 \mathrm{~m} \times 10 \mathrm{~m}$ untuk pengamatan tingkat tiang, $5 \mathrm{~m} \times 5 \mathrm{~m}$ untuk pengamatan tingkat pancang dan $2 \mathrm{~m} \times 2$ $m$ untuk tingkat semai dan tumbuhan bawah.

Gambar 2 Sub-petak pengamatan 
dengan ukuran $20 \mathrm{~m}$ x $20 \mathrm{~m}$, sehingga pada setiap plot pengamatan $100 \mathrm{~m} \times 100 \mathrm{~m}$ terdapat 25 sub-plot contoh. Total seluruh sub-plot berjumlah 50 sub-plot pada setiap lokasi pengamatan.

\section{Pengambilan Data Lapangan}

Pengambilan data dengan cara analisis vegetasi yaitu pada tingkat tiang dan pohon khususnya puspa $(S$. wallichi) dalam setiap sub-plot contoh ukuran $20 \mathrm{~cm}$ x 20 $\mathrm{cm}$. Data tiang dan pohon diambil nama jenis, tinggi total dan diameter. Tingkat pancang, semai dan tumbuhan bawah diambil nama jenisnya saja. Struktur tegakan diuraikan melalui struktur horizontal dan struktur vertikal tegakan. Struktur horizontal dan vertikal disajikan dalam sebaran kelas dan diagram profil. Diagram profil tajuk didapatkan dari data profil yang diambil di lapangan, direkap ke dalam Ms. Excel kemudian diolah menggunakan software SExI- FS.

\section{Analisis Data}

\section{Indeks Nilai Penting (INP)}

Indeks nilai penting digunakan untuk mengetahui seberapa besar jenis dapat mendominasi pada lokasi tertentu. Menurut Cox (1927) dalam Prasetyo (2006) pengolahan INP diperoleh dari: $\mathrm{INP}=\mathrm{KR}+\mathrm{FR}+\mathrm{DR}$ (pancang, tiang dan pohon), INP $=\mathrm{KR}+\mathrm{FR}$ (semai dan tumbuhan bawah), dimana:

$$
\begin{gathered}
\text { a. Kerapatan suatu jenis (K) (ind/ha) } \\
\mathrm{K}=\frac{\sum \text { individu suatu jenis }}{\text { Luas petak contoh }}
\end{gathered}
$$

b. Kerapatan relatif suatu jenis (KR) (\%)

$$
\mathrm{KR}=\frac{\mathrm{K} \text { suatu jenis }}{\mathrm{K} \text { semua jenis }} \times 100 \%
$$

c. Frekuensi suatu jenis (F) (ind/ha)

$$
\mathrm{F}=\frac{\sum \text { sub petak ditemukan suatu jenis }}{\sum \text { seluruh sub petak contoh }}
$$

d. Frekuensi relatif suatu jenis (FR) (\%)

$$
\mathrm{FR}=\frac{\mathrm{F} \text { suatu jenis }}{\mathrm{F} \text { semua jenis }} \times 100 \%
$$

e. Dominansi suatu jenis (D) $\left(\mathrm{m}^{2} / \mathrm{ha}\right)$ untuk pohon

$$
\mathrm{D}=\frac{\text { Luas bidang dasar suatu jenis }}{\text { Luas petak contoh }}
$$

f. Luas bidang dasar $\left(\mathrm{m}^{2}\right)$ suatu pohon dapat diperoleh dengan rumus

$$
\text { LBDS }=\pi R^{2}={ }_{4}^{1} \pi D^{2}
$$

g. Dominasi relatif suatu jenis (DR)

$$
\mathrm{DR}=\frac{\mathrm{D} \text { suatu jenis }}{\mathrm{D} \text { semua jenis }} \times 100 \%
$$

\section{Indeks Keanekaragaman Jenis}

Keanekaragaman jenis dikemukakan pertama kali oleh Good (1953) dalam Magurran (1988). Rumus dari Shannon- Wiener Index of General Diversty adalah:

$$
\begin{array}{ll}
\mathrm{H}^{\prime}= & -\sum_{i=1}^{n}\left(\left(\frac{n i}{N}\right) \ln \left(\frac{n i}{N}\right)\right) \text {, dimana: } \\
\mathrm{H}^{\prime} \quad=\text { Shannon-Wiener Index of General diversity } \\
n i_{\mathrm{i}} \quad=\text { Indeks nilai penting jenis } \mathrm{i} \\
\mathrm{N} \quad=\text { Total Indeks Nilai Penting }
\end{array}
$$

\section{Indeks Kemerataan Jenis}

Indeks kemerataan jenis menunjukkan kemerataan individu setiap jenis dalam suatu areal. Indeks kemerataan jenis dapat dihitung dengan menggunakan rumus sebagai berikut (Pielou 1975 dalam Magurran 1988)

$$
\begin{aligned}
& \mathrm{E}=\frac{\mathrm{H}^{\prime}}{\ln \mathrm{S}}, \text { dimana: } \\
& \mathrm{E} \quad=\text { Indeks kemerataan Jenis } \\
& \mathrm{H}^{\prime} \quad=\text { Indeks keanekaragaman Jenis } \\
& \mathrm{S} \quad=\text { Jumlah jenis diamati }
\end{aligned}
$$

\section{Indeks Kekayaan Jenis}

Indeks Margallef dapat digunakan untuk mengetahui kekayaan jenis di suatu areal Ludwig dan Reynold (1988) dalam Parinda (2011).

$$
\begin{aligned}
& \mathrm{R}=\frac{\mathrm{S}-1}{\ln (\mathrm{N})}, \text { dimana: } \\
& \mathrm{R}_{1} \quad=\text { Indeks kekayaan jenis Margallef } \\
& \mathrm{S} \quad=\text { Jumlah jenis } \\
& \mathrm{N} \quad=\text { Jumlah total individu }
\end{aligned}
$$

\section{Indeks Dominansi Jenis}

Penentuan kriteria indeks dominasi Menurut Simpsons (1949) dalam Odum (1993) adalah menggunakan rumus sebagai berikut:

$$
\begin{aligned}
& \text { ID }=\sum_{\mathrm{i}}^{\mathrm{n}}\left(\frac{\mathrm{ni}}{\mathrm{N}}\right)^{2} \text {, dimana: } \\
& \mathrm{ID} \quad=\text { Indeks Dominansi } \\
& \mathrm{ni} \quad=\text { Indeks Nilai Penting jenis ke-i } \\
& \mathrm{N} \quad=\text { Jumlah Indeks Nilai Penting seluruh jenis }
\end{aligned}
$$

\section{Indeks Penyebaran Jenis}

Indeks Morisita (I $\delta$ ) merupakan nilai yang digunakan untuk melihat penyebaran jenis yang mengelompok atau tidak. Pola sebaran dapat diketahui dengan rumus berikut:

a. Indeks Morisita (Iס) (Morisita 1959):

$$
\mathrm{I} \delta=\mathrm{n} \frac{\left(\sum X i^{2}-\sum \mathrm{Xi}\right)}{\left(\sum X i\right)^{2}-\sum X \mathrm{X}}, \text { dimana: }
$$

$\mathrm{I} \delta \quad=$ Indeks Morista

$\sum \mathrm{Xi}=$ Jumlah individu tiap petak

$\mathrm{n} \quad=$ Jumlah petak pengamatan 
b. Mu dan Mc (Jongjitvimol et al. 2005):

$$
\begin{array}{ll}
M u=\frac{\left(X_{0.975}^{2}-\mathrm{n}+\sum \mathrm{Xi}\right)}{\left(\sum \mathrm{Xi}\right)-1} & \\
M c=\frac{\left(X_{0.025}^{2}-\mathrm{n}+\sum \mathrm{Xi}\right)}{\left(\sum \mathrm{Xi}\right)-1}, \text { dimana: } \\
M u=\begin{array}{l}
\text { indeks penyebaran Morisita untuk pola } \\
\text { sebaran seragam }
\end{array} \\
X_{0.975=} \begin{array}{l}
\text { nilai chisquare derajat bebas } \mathrm{n}-1 \text { dan } \\
\text { selang kepercayaan } 97.5 \%
\end{array} \\
M c=\begin{array}{l}
\text { indeks penyebaran Morisita untuk pola } \\
\text { sebaran mengelompok }
\end{array} \\
X_{0.025=} \begin{array}{l}
\text { indeks nilai chisquare derajat bebas } \mathrm{n}-1 \\
\text { selang kepercayaan } 2.5 \%
\end{array}
\end{array}
$$

c. Menghitung Standar derajat Morisita (Jongjitvimol et al. 2005):

$$
\begin{aligned}
& \mathrm{Ip}=0.5+0.5\left(\frac{\mathrm{I} \delta-\mathrm{Mc}}{n-M c}\right): \mathrm{jika} \mathrm{I} \delta \geq \mathrm{Mc}>1,0 \\
& \mathrm{Ip}=0,5\left(\frac{\mathrm{I} \delta-1}{M c-1}\right): \text { jika } \mathrm{Mc}>\mathrm{I} \delta \geq 1,0 \\
& \mathrm{Ip}=-0,5\left(\frac{\mathrm{I} \delta-1}{M u-1}\right): \text { jika } 1,0>\mathrm{I} \delta \geq \mathrm{Mu} \\
& \mathrm{Ip}=-0,5+0,5\left(\frac{\mathrm{I} \delta-\mathrm{Mu}}{M u}\right): \text { jika } 1,0>\mathrm{Mu} \geq \mathrm{I} \delta
\end{aligned}
$$

Jika Ip $<0$ maka pola sebarannya seragam, jika Ip=0 maka pola sebarannya acak, dan jika Ip $>0$ maka pola sebarannya mengelompok.

\section{HASIL DAN PEMBAHASAN}

\section{Komposisi Jenis Tumbuhan}

Analisis vegetasi adalah suatu cara untuk mempelajari susunan dan komposisi vegetasi dalam suatu komunitas tumbuhan (Junaedi 2008 dalam Ibadurrohman 2016). Berdasarkan analisis vegetasi yang telah dilakukan pada Blok Pamengpeuk dan Blok Leles diperoleh hasil sebanyak 98 jenis tumbuhan yang terdiri atas 50 famili. Famili terbanyak yang ditemukan yaitu dari Fagaceae dan Moraceae masing-masing 6 jenis, diikuti dengan Lauraceae dan Arecaceae masing-masing sebanyak 5 jenis. Jumlah jenis tumbuhan pada masingmasing tingkat pertumbuhan disajikan pada Tabel 1.

Tabel 1 Komposisi jenis tumbuhan pada kedua lokasi penelitian

\begin{tabular}{lcc}
\hline \multirow{2}{*}{$\begin{array}{c}\text { Tingkat } \\
\text { pertumbuhan }\end{array}$} & \multicolumn{2}{c}{ Jumlah jenis } \\
\cline { 2 - 3 } & $\begin{array}{c}\text { Blok } \\
\text { Pamengpeuk }\end{array}$ & Blok Leles \\
\hline Tumbuhan bawah & 24 & 23 \\
Semai & 13 & 6 \\
Pancang & 12 & 12 \\
Tiang & 19 & 11 \\
Pohon & 34 & 14 \\
\hline
\end{tabular}

Berdasarkan Tabel 1 jenis yang dijumpai di Blok Pamengpeuk tingkat pertumbuhan tumbuhan bawah, semai, pancang, tiang dan pohon memiliki jenis terbanyak dibandingkan Blok Leles dengan jumlah jenis berturut-turut adalah 24, 13, 19 dan 34 jenis. Sedangkan pada pertumbuhan tingkat pancang di Blok Pamengpeuk dan tingkat pertumbuhan tiang di Blok Leles memiliki jumlah jenis yang tergolong kecil, hal ini terjadi karena mulai terjadi persaingan pada tahapan ini yang mengakibatkan beberapa jenis tidak mampu bertahan. Jenis tumbuhan bawah banyak ditemukan di kedua lokasi baik di Blok Pamengpeuk maupun di Blok Leles yaitu masing-masing sebanyak 24 dan 23 jenis. Tumbuhan bawah sangat dipengaruhi oleh sinar matahari yang masuk ke lantai hutan. Menurut Hilwan dan Masyrafina (2015) sinar matahari yang berlimpah akan memicu pertumbuhan dan perkembangan tumbuhan bawah yang bersifat intoleran. Pada tingkat tiang dan pohon di Blok Pamengpeuk disusun oleh lebih banyak jenis, artinya kondisi lingkungan yang alami memberi kesempatan tumbuh yang lebih banyak bagi vegetasi (Haryadi 2017). Kerapatan jenis pada lokasi penelitian disajikan pada Tabel 2.

Berdasarkan Tabel 2 kerapatan jenis puspa di Blok Leles lebih besar dibandingkan dengan Blok Pamengpeuk. Hal ini diduga karena terjadinya perambahan pada Blok Leles yang menyebabkan perubahan vegetasi dari hutan primer menjadi hutan sekunder yang didominasi dengan jenis puspa, sehingga jenis puspa banyak di temukan di Blok Leles. Selain banyaknya puspa yang ditanami kembali oleh pihak Taman Nasional Gunung Halimun Salak, pohon puspa di Blok Leles juga tumbuh alami dari biji buah pohon induk yang jatuh ke tanah. Tabel 2 menunjukkan tingginya kerapatan pertumbuhan tingkat semai di kedua lokasi. Menurut Meyer (1952) dalam Kusmana dan Susanti (2015), kondisi hutan dengan banyak semai akan menjamin kelestarian hutan di masa yang akan datang karena jumlah individu permudaan jauh lebih banyak daripada jumlah individu pohon dewasa, dimana stok permudaan tersebut sangat penting untuk memelihara kemampuan regenerasi hutan.

\section{Struktur Tegakan}

Struktur tegakan vertikal dan horizontal disajikan pada Gambar 3 dan Gambar 4. Berdasarkan Gambar 3 semakin besar ukuran diameter, maka kerapatan

Tabel 2 Kerapatan jenis puspa dan jenis lain pada kedua lokasi penelitian

\begin{tabular}{lcccc}
\hline & \multicolumn{2}{c}{$\begin{array}{c}\text { Blok } \\
\text { Pamengpeuk } \\
\text { Tingkat } \\
\text { pertumbuhan }\end{array}$} & \multicolumn{2}{c}{$\begin{array}{c}\text { Blok Leles } \\
\text { (ind/ha) }\end{array}$} \\
\cline { 2 - 5 } & Puspa & $\begin{array}{c}\text { Jenis } \\
\text { lain }\end{array}$ & Puspa & $\begin{array}{c}\text { Jenis } \\
\text { lain }\end{array}$ \\
\hline Semai & 200 & 5500 & 1200 & 8300 \\
Pancang & 16 & 1120 & 224 & 514 \\
Tiang & 4 & 84 & 1312 & 96 \\
Pohon & 3 & 122 & 108 & 20 \\
\hline
\end{tabular}


individunya cenderung semakin sedikit. Menurut Kusmana dan Susanti (2015) sebaran yang menyerupai huruf "J" terbalik berarti kerapatan individu pohon yang tumbuh pada masa awal pertumbuhan memerlukan energi seiring berjalannya waktu sehingga terjadi persaingan dalam mendapatkan sinar matahari. Sebaran seperti ini akan menjamin keberlangsungan tegakan hutan di masa yang akan datang. Gambar 8 menunjukkan kerapatan individu jenis lain membentuk $\mathrm{J}$ terbalik pada kedua lokasi, sedangkan pada Gambar 4 jenis puspa pada tiap diameter menunjukkan jumlah yang sedikit dibandingkan jenis lain kecuali pada kelas diameter 20$40 \mathrm{~cm}$ di Blok Leles dimana terdapat 107 individu/ha. Pada kelas diameter $100-120 \mathrm{~cm}$ dan $>120 \mathrm{~cm}$ pada kedua lokasi tidak ditemukan kehadiran individu jenis puspa.

Struktur vertikal suatu tegakan diketahui dengan mengelompokkan berdasarkan kelas tinggi mengikuti stratum pohon, yakni stratum C (tinggi 4-20m), stratum B (20-30m), dan stratum A (>30m) (Kusmana et al. 2009). Berdasarkan klasifikasi tersebut dapat dilihat pada Gambar 5 dan 6 jumlah individu jenis puspa dan jenis lain paling banyak terdapat pada kelas tinggi $4-20 \mathrm{~m}$. Pola sebaran kelas tinggi menunjukkan jumlah individu semakin menurun seiring bertambahnya tinggi pohon, dikarenakan sulitnya mencapai stratum A dan stratum B. Keadaan tersebut disebabkan oleh cukup lamanya waktu yang dibutuhkan untuk mencapai stratum A dan B serta

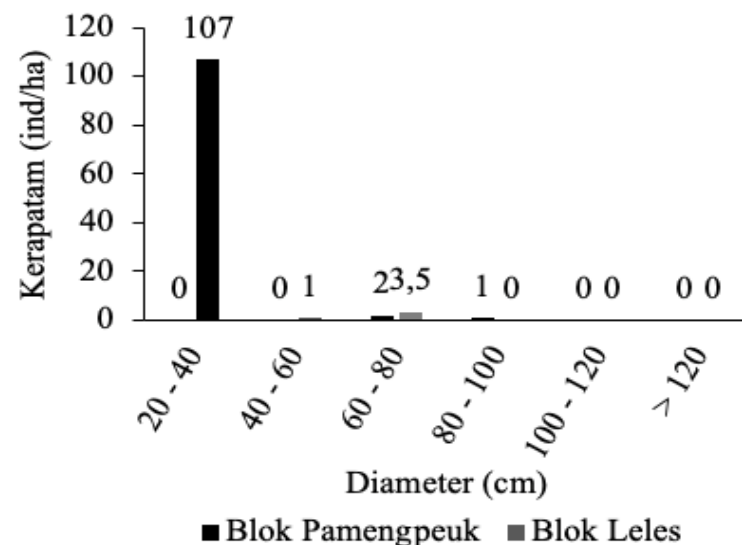

Gambar 3 Grafik sebaran kelas diameter puspa di lokasi penelitian

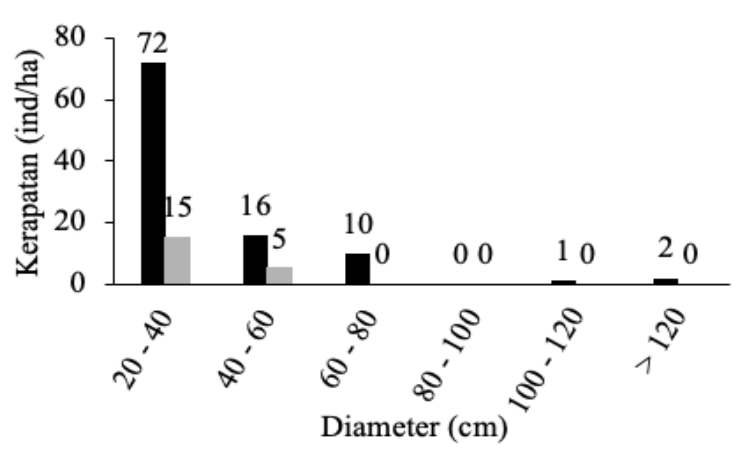

- Blok Pamengpeuk $\backsim$ Blok Leles

Gambar 4 Grafik sebaran kelas diameter jenis lain di lokasi penelitian persaingan yang cukup tinggi, baik untuk memperoleh nutrisi, air tanah, maupun cahaya. Kondisi hutan seperti ini akan menjamin kelestarian hutan di masa yang akan datang karena stok permudaan tersebut sangat penting untuk memelihara kemampuan regenerasi hutan (Susanti 2014) dalam Istomo dan Sari (2019).

\section{Indeks Nilai Penting}

Indeks Nilai Penting merupakan nilai yang digunakan untuk mengetahui dominansi suatu jenis (Ibadurrohmah 2016) Tabel 3 menyajikan daftar jenis INP tertinggi pada kedua lokasi penelitian. Berdasarkan Tabel 3 dapat diketahui bahwa jenis puspa termasuk jenis tumbuhan yang termasuk ke dalam tiga teratas dengan INP tertinggi di Blok Leles dimana pada tingkat semai, pancang, tiang dan pohon masing-masing memiliki nilai INP sebesar $45,96 \%, 58,02 \%, 243,32 \%$, dan $218,18 \%$. Hal ini membuat jenis puspa dikatakan sebagai jenis tumbuhan yang dominan karena dapat dijumpai di setiap tingkat pertumbuhan Mawazin dan Subiakto (2013) juga menjelaskan bahwa jenis-jenis yang mempunyai INP tertinggi berpeluang lebih besar untuk dapat mempertahankan pertumbuhan dan kelestarian jenisnya. Smith (1977) dalam Rosalia (2008) menyatakan jenis dominan adalah jenis yang dapat memanfaatkan lingkungan yang ditempatinya secara efisien. Pertumbuhan jenis puspa tingkat semai, pancang, tiang dan pohon pada Blok Pamengpeuk memiliki nilai INP yang tergolong rendah, dimana masing-masing memiliki

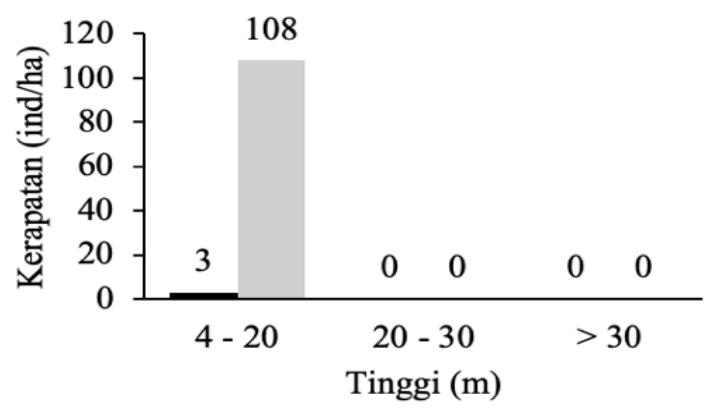

- Blok Pamengpeuk Blok Leles

Gambar 5 Grafik sebaran kelas tinggi puspa di lokasi penelitian

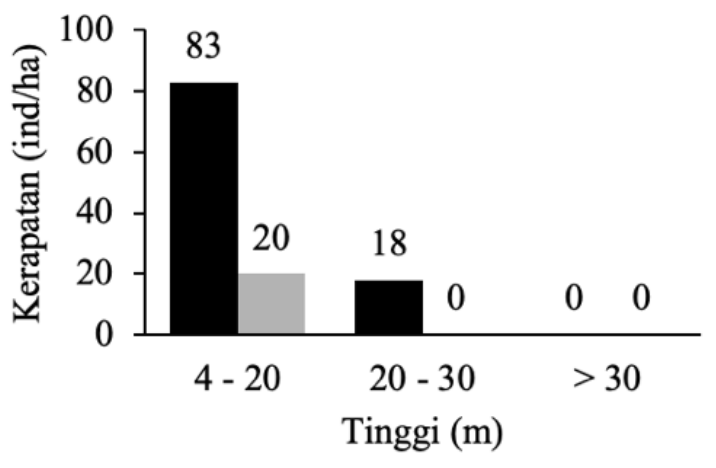

- Blok Pamengpeuk Blok Leles

Gambar 6 Grafik sebaran kelas tinggi jenis lain di lokasi penelitian 
nilai INP sebesar $10,41 \%, 4,04 \%, 14,31 \%$ dan $9,83 \%$. Hal ini disebabkan pada Blok Pamengpeuk terdapat jenisjenis yang lebih mendominasi seperti Ostodes paniculata pada tingkat pohon, Sloanea sigun pada tingkat tiang, Castanopsis argentea pada tingkat pancang dan Symplocos fasiculata pada tingkat semai.

\section{Dominansi dan Keanekaragaman Jenis}

Tingkat keanekaragaman jenis dapat diketahui berdasarkan indeks dominansi, indeks keanekaragaman, indeks kekayaan, dan indeks kemerataan jenis. Nilai indeks dominansi dari kedua lokasi penelitian dapat dilihat pada Tabel 4.

Parameter yang menyatakan tingkat terpusatnya dominansi atau penguasaan jenis dalam suatu komunitas disebut indeks dominansi Indriyanto (2006) dalam Mulyana (2015). Simpsons (1949) dalam Odum (1993) menjelaskan bahwa nilai indeks dominansi berkisar $0 \leq$ $\mathrm{C} \leq 1$. Jika nilai $0,75 \leq \mathrm{C} \leq 1$ maka dominansi tergolong tinggi. Jika nilai $0,5 \leq \mathrm{C} \leq 0,75$ maka dominansi tergolong sedang. Jika nilai $0 \leq \mathrm{C} \leq 0,5$ maka dominansi tergolong rendah. Berdasarkan klasifikasi tersebut didapatkan dari Tabel 4 bahwa Blok Pamengpeuk memiliki nilai indeks dominansi yang rendah pada semua tingkat pertumbuhan, hal ini menunjukkan bahwa dominansi tidak terpusat pada salah satu komunitas tumbuhan tertentu. Sedangkan Blok Leles pada pertumbuhan tingkat tiang dan pohon memiliki nilai indeks dominansi lebih besar dan tergolong tinggi dibanding Blok Pamengpeuk, hal ini menandakan bahwa Blok Leles pola penguasaan jenisnya lebih terpusat pada jenis tertentu yaitu pada jenis puspa (S. wallichii). Tabel 5 dan Tabel 6 menyajikan nilai indeks keanekaragaman, kemerataan dan kekayaan jenis di kedua lokasi penelitian.

Tingkat keanekaragaman jenis tumbuhan pada suatu komunitas hutan dapat dianalisis dengan menggunakan indeks keanekaragaman (H'). Nilai keanekaragaman atau H' di Blok Leles berkisar antara 1,07-2,90 lebih tinggi dibandingkan Blok Pamengpeuk yang hanya berkisar antara 0,81-1,99 saja. Kriteria menurut Magurran (1988) jika nilai indeks keanekaragaman jenis $H^{\prime}<1.5$ menunjukkan kekayaan jenis yang tergolong rendah, sedangkan jika nilai $\mathrm{H}^{\prime}$ antara 1.5 dan 3.5 tergolong sedang dan H'>3.5 menunjukkan keanekaragaman yang tergolong tinggi. Berdasarkan klasifikasi tersebut, dapat dikatakan pada Blok Leles keanekaragaman jenisnya tergolong sedang, sedangkan pada Blok Pamengpeuk nilai termasuk rendah. Keanekaragaman jenis di suatu daerah tidak hanya ditentukan oleh banyaknya jenis, tetapi juga oleh banyaknya individu setiap jenis (Mahali 2008 dalam Afnani 2004). Menurut Lahusen et al. (2014) dalam Istomo dan Sari (2019), nilai indeks keanekaragaman yang besar mengisyaratkan terdapatnya daya dukung lingkungan yang besar terhadap kelangsungan hidup serta menunjukkan semakin stabilnya ekosistem tersebut.

Indeks yang dapat digunakan untuk menetapkan kemantapan atau kestabilan jenis dalam suatu komunitas disebut Indeks kemerataan (E). Mawazin dan Subiakto (2013) dalam Ibadurrohmah (2016) menjelaskan bahwa suatu komunitas yang memiliki tingkat kestabilan yang tinggi akan memiliki peluang yang lebih besar dalam

Tabel 4 Nilai indeks dominansi pada masing-masing lokasi penelitian

\begin{tabular}{lcccc}
\hline \multirow{2}{*}{$\begin{array}{c}\text { Tingkat } \\
\text { pertumbuh } \\
\text { an }\end{array}$} & \multicolumn{2}{c}{ Blok Pamengpeuk } & \multicolumn{2}{c}{ Blok Leles } \\
\cline { 2 - 5 } & ID & Ket & ID & Ket \\
\hline Tumb. & 0,109 & Rendah & 0,161 & Rendah \\
Bawah & 0,106 & Rendah & 0,348 & Rendah \\
Semai & 0,120 & Rendah & 0,162 & Rendah \\
Pancang & 0,060 & Rendah & 0,662 & Tinggi \\
Tiang & 0,094 & Rendah & 0,537 & Tinggi \\
Pohon & 0,094 & & & \\
\hline
\end{tabular}

Tabel 3 Daftar jenis INP tertinggi pada kedua lokasi penelitian

\begin{tabular}{|c|c|c|c|c|c|c|}
\hline \multirow{2}{*}{$\begin{array}{l}\text { Tingkat } \\
\text { pertumbu- } \\
\text { han }\end{array}$} & \multicolumn{3}{|c|}{ Blok Pamengpeuk } & \multicolumn{3}{|c|}{ Blok Leles } \\
\hline & No & Nama spesies & $\begin{array}{l}\text { INP } \\
(\%)\end{array}$ & No & Nama spesies & $\begin{array}{l}\text { INP } \\
(\%)\end{array}$ \\
\hline \multirow{3}{*}{$\begin{array}{l}\text { Tumb. } \\
\text { bawah }\end{array}$} & 1 & Achasma megalacheios & 39,70 & 1 & Selaginella unsinata & 57,41 \\
\hline & 2 & Ludwigia octalvis & 33,43 & 2 & Clidemia hirta & 52,17 \\
\hline & 3 & Begonia glabra & 30,85 & 3 & Amтотит compactum & 17,43 \\
\hline \multirow{4}{*}{ Semai } & 1 & Symplocos fasiculata & 40,11 & 1 & Chromolaena odorata & 81,20 \\
\hline & 2 & Urophyllum arboreum & 24,38 & 2 & Schima wallichii & 45,96 \\
\hline & 3 & Daphiniphylum glaucescens & 20,93 & 3 & Panicum palmifolium & 43,26 \\
\hline & 10 & Schima wallichii & 10,41 & 4 & Symplocos cochinchinensis & 8,97 \\
\hline \multirow{4}{*}{ Pancang } & 1 & Castanopsis argentea & 36,73 & 1 & Schima wallichii & 58,02 \\
\hline & 2 & Ostodes paniculata & 31,28 & 2 & Calliandra calothyrsus & 46,78 \\
\hline & 3 & Symplocos fasiculata & 28,47 & 3 & Symplocos fasiculata & 29,01 \\
\hline & 12 & Schima wallichii & 4,04 & 4 & Machilus rimota & 15,59 \\
\hline \multirow{4}{*}{ Tiang } & 1 & Sloanea sigun & 33,61 & 1 & Schima wallichii & 243,32 \\
\hline & 2 & Ostodes paniculata & 28,61 & 2 & Calliandra calothyrsus & 7,15 \\
\hline & 3 & Piper anducum & 21,35 & 3 & Symplocos fasiculata & 2,71 \\
\hline & 11 & Schima wallichii & 14,31 & 4 & Artocarpus heterophyllus & 6,14 \\
\hline \multirow{4}{*}{ Pohon } & 1 & Ostodes paniculata & 62,01 & 1 & Schima wallichii & 218,18 \\
\hline & 2 & Castanopsis argentea & 43,23 & 2 & Persea americana & 18,54 \\
\hline & 3 & Dysoxylum excelsum & 37,23 & 3 & Trema orientalis & 12,21 \\
\hline & 7 & Schima wallichii & 9,83 & 4 & Artocarpus heterophyllus & 8,21 \\
\hline
\end{tabular}


melestarikan kelestarian jenisnya. Menurut Krebs (1989) dalam Afnani (2004) jika nilai $\mathrm{E}<0,2$ maka penyebaran jenis tidak stabil atau tidak merata, sedangkan jika nilai $0,2 \leq \mathrm{E} \leq 1$ maka penyebaran stabil dan merata. Berdasarkan klasifikasi tersebut, dapat dilihat dari Tabel 5 pada Blok Pamengpeuk memiliki nilai kemerataan yang tinggi karena nilai kemerataan (E) tidak kurang dari 0,2 . Hal ini menunjukkan bahwa hampir seluruh jenis pada setiap tingkat pertumbuhan dan tumbuhan bawah di kedua lokasi memiliki jumlah individu yang merata. Sedangkan pada Blok Leles pada tingkat pertumbuhan tiang dan pohon memiliki nilai kemerataan yang tergolong rendah yang menyatakan bahwa penyebaran jenisnya tidak stabil dan merata.

Kekayaan jenis tumbuhan dalam suatu komunitas dapat diketahui dengan menggunakan rumus indeks kekayaan jenis $\left(\mathrm{R}_{1}\right)$. Berdasarkan pernyataan Magurran (1988) dimana jika $\mathrm{R}_{1}<3,5$ maka kekayaan jenisnya tergolong rendah, jika nilai $\mathrm{R}_{1}=3,5-5,0$ maka kekayaan jenis tergolong sedang dan jika nilai $R_{1}>5,0$ maka kekayaan jenisnya tergolong tinggi. Blok Pamengpeuk memiliki nilai kekayaan jenis yang bervariasi yang tergolong rendah, sedang hingga tinggi. Nilai $\mathrm{R}_{1}$ yang tergolong sedang berada pada tingkat tumbuhan bawah, sedangkan nilai $\mathrm{R}_{1}$ yang tergolong rendah ada pada pertumbuhan tingkat semai dan pancang dan pada tingkat tiang dan pohon nilai kekayaan jenisnya tergolong tinggi, dimana masing-masing memiliki nilai $\mathrm{R}_{1} 5,82$ dan 6,83. Nilai kekayaan jenis pada Blok Leles di pertumbuhan tingkat semai, pancang, tiang dan pohon tergolong rendah karena nilai $\mathrm{R}_{1}<3,5$ sedangkan pada pertumbuhan tingkat tanaman bawah kekayaan jenis yang tergolong

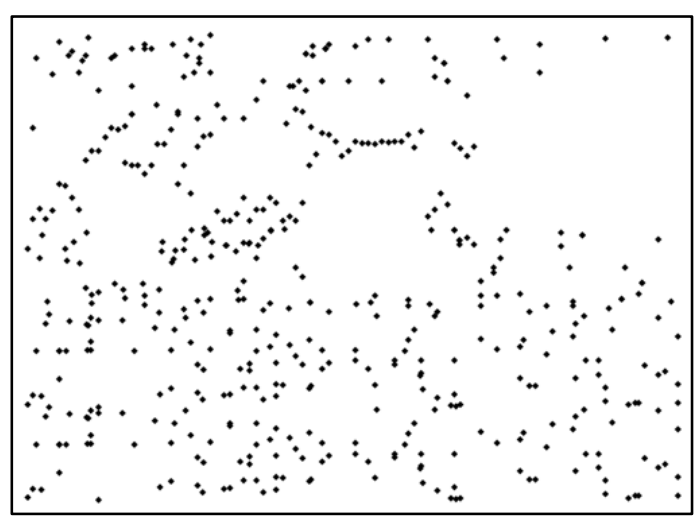

Gambar 11 Peta sebaran jenis puspa di Blok Leles

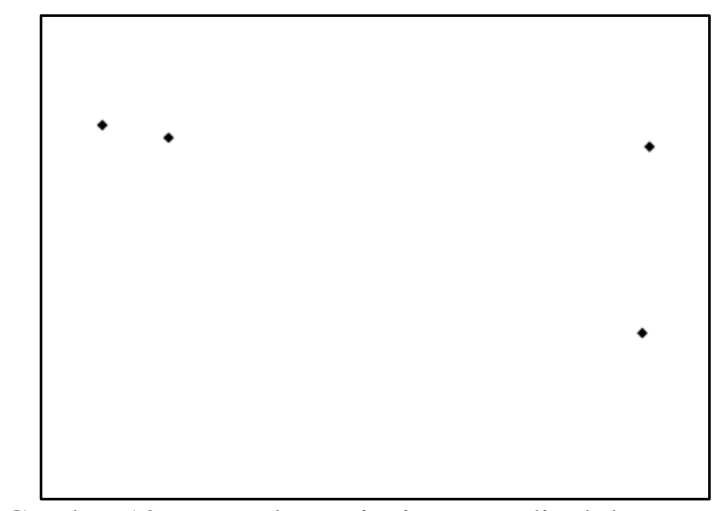

Gambar 12 Peta sebaran jenis puspa di Blok Pamengpeuk sedang. Kekayaan jenis berbanding lurus dengan banyaknya jenis pada suatu komunitas dimana semakin banyak jenis tumbuhan pada komunitas tersebut maka akan semakin tinggi pula nilai $R_{1}$ yang dimiliki (Ibadurrohmah 2016).

\section{Sebaran Jenis Puspa (Schima wallichii)}

Berdasarkan hasil analisis indeks morisita (I $\delta$ ), pada Tabel 7 disajikan pola penyebaran jenis puspa $(S$. wallichii). Pola sebaran suatu spesies dapat diidentifikasi dengan berbagai macam indeks sebaran, salah satu di antaranya adalah menggunakan Indeks Morisita dan Standarisasi Indeks Morisita (Rani 2003). Penelitian Rani (2013) membuktikan bahwa indeks ini merupakan metode terbaik untuk mengukur pola sebaran suatu individu karena tidak bergantung terhadap kepadatan populasi dan ukuran sampel.

Berdasarkan hasil analisis pola sebaran pada Tabel 7 jenis puspa memiliki nilai Ip $>0$ baik di Blok Pamengpeuk maupun di Blok Leles maka pola sebarannya adalah mengelompok, seperti yang dijelaskan oleh Jongjitvimol et al. (2015) pola sebaran dapat ditentukan berdasarkan nila Ip, jika Ip $<0$ maka pola sebarannya seragam, jika $\mathrm{Ip}=0$ maka pola sebarannya acak dan jika Ip>0 maka pola sebarannya mengelompok.

Menurut Purnama et al. (2016) keberadaan pohon puspa yang mengelompok menandakan adanya pertumbuhan anakan yang baik dari pohon induk di sekitarnya. Hal ini juga dijelaskan dalam penelitian

Tabel 5 Nilai indeks keanekaragaman (H'), kemerataan $(E)$, dan kekayaan $\left(\mathrm{R}_{1}\right)$ jenis di Blok Pamengpeuk

\begin{tabular}{lccc}
\hline \multirow{2}{*}{$\begin{array}{c}\text { Tingkat } \\
\text { Pertumbuhan }\end{array}$} & \multicolumn{3}{c}{ Blok Pamengpeuk } \\
\cline { 2 - 4 } & $\mathrm{H}^{\prime}$ & $\mathrm{E}$ & $\mathrm{R}_{1}$ \\
\hline Tumb.Bawah & 2,34 & 0,74 & 4,01 \\
Semai & 2,23 & 0,87 & 2,97 \\
Pancang & 2,21 & 0,89 & 2,58 \\
Tiang & 2,90 & 0,99 & 5,82 \\
Pohon & 1,07 & 0,77 & 6,83 \\
\hline
\end{tabular}

Tabel 6 Nilai indeks keanekaragaman (H'), kemerataan $(E)$, dan kekayaan $\left(R_{1}\right)$ jenis di Blok Leles

\begin{tabular}{lccc}
\hline \multirow{2}{*}{$\begin{array}{c}\text { Tingkat } \\
\text { Pertumbuhan }\end{array}$} & \multicolumn{3}{c}{ Blok Leles } \\
\cline { 2 - 4 } & $\mathrm{H}^{\prime}$ & $\mathrm{E}$ & $\mathrm{R}_{1}$ \\
\hline Tumb.Bawah & 1,99 & 0,64 & 3,35 \\
Semai & 1,07 & 0,60 & 1,59 \\
Pancang & 1,98 & 0,80 & 2,83 \\
Tiang & 0,97 & 0,16 & 1,71 \\
Pohon & 0,81 & 0,31 & 2,68 \\
\hline
\end{tabular}

Tabel 7 Pola penyebaran Puspa (S. wallichii) di lokasi penelitian

\begin{tabular}{|c|c|c|c|c|}
\hline Lokasi & Jenis & $\begin{array}{c}\text { Indeks } \\
\text { Morisita } \\
\end{array}$ & Ip & $\begin{array}{c}\text { Pola } \\
\text { Sebaran } \\
\end{array}$ \\
\hline $\begin{array}{l}\text { Blok } \\
\text { Pamengpeuk }\end{array}$ & Puspa & 1,19 & 0,03 & $\begin{array}{l}\text { Mengelom- } \\
\text { pok }\end{array}$ \\
\hline Blok Leles & Puspa & 1,17 & 0,50 & $\begin{array}{l}\text { Mengelom- } \\
\text { pok }\end{array}$ \\
\hline
\end{tabular}


Arrijani (2008) dalam Istomo dan Sari (2019) yang mengemukakan pada pola mengelompok, biji dari setiap tumbuhan akan jatuh dan terjadi anakan baru di sekitar pohon induk. Jika ketersediaan hara dan nutrisi cukup untuk pertumbuhan suatu jenis, maka akan terbentuk pola penyebaran mengelompok. Istomo dalam Afnani (2014) menyatakan bahwa individu akan berkelompok di tempat-tempat yang lebih menguntungkan. Hal ini karena adanya interaksi yang saling menguntungkan antara individu-individu tersebut.

\section{SIMPULAN DAN SARAN}

\section{Simpulan}

Pola penyebaran puspa (S. wallichii) di Resort Kawah Ratu, Taman Nasional Gunung Halimun Salak adalah mengelompok, baik di Blok Pamengpeuk maupun di Blok Leles. Penyebaran mengelompok menandakan adanya pertumbuhan permudaan yang baik. Kemampuan regenerasi puspa di kedua lokasi tergolong baik karena jumlah individu permudaan puspa lebih banyak daripada individu pohonnya.

\section{Saran}

Perlu adanya penelitian lebih lanjut mengenai hubungan faktor lingkungan dan penyebaran jenis puspa. Meskipun kemampuan regenerasi permudaan puspa tergolong baik, namun tetap diperlukan tindakan pemeliharaan hutan secara rutin.

\section{DAFTAR PUSTAKA}

Afnani M. 2014. Potensi dan sebaran jenis meranti (Shorea spp.) pada Kawasan Lindung PT. Wana Hijau Pesaguan, Kalimantan Barat [skripsi] Bogor: IPB University.

Alhamd L, Polosakan R. 2011. Komposisi jenis dan struktur vegetasi di hutan Kawasan Taman Nasional Gunung Halimun Salak Sukabumi. Berkas Penelitian Hayati Edisi Khusus: 5A: 1-4.

Aprianti F. 2013. Teknik pemanfaatan anakan alam puspa (Schima wallichii (DC.) Korth) di Hutan Pendidikan Gunung Walat Sukabumi [skripsi] Bogor: IPB University.

Buharman, Djam'an DF, Widyani N, Sudradjat S. 2011. Atlas Benih Tanaman Indonesia Jilid II. Bogor: Badan Penelitian dan Pengembangan Kehutanan Departemen Kehutanan.

Dendang B, Handayani W. 2015. Struktur dan komposisi tegakan hutan di Taman Nasional Gunung Gede Pangrango, Jawa Barat. Surakarta: Masyarakat Biodiversitas Indonesia.

GHSNMP-JICA. 2007. Gunung Halimun Salak National Park, The Misty Mountains of Halimun Salak. Sukabumi: Gunung Halimun Salak National Park.

Haryadi N. Struktur dan komposisi vegetasi pada kawasan lindung Air Terjun Telaga Kameloh Kabupaten Gunung Mas. Jurnal zira'ah 42(2): 137-149.
Hilwan I, Masyrafina I. 2015. Keanekaragaman jenis tumbuhan bawah di Gunung Papandayan Bagian Timur, Garut, Jawa Barat. Jurnal silvikultur tropika 6(2): 119-125.

Ibadurrohmah N. 2016. Pola penyebaran dan regenerasi puspa (Schima wallichii (DC.) Korth.) di Resort Selabintana Taman Nasional Gunung Gede Pangrango [skripsi] Bogor: IPB University.

Istomo, Sari PN. 2019. Penyebaran dan karakteristik habitat jenis rasamala (Altingia excelsa Noronha) di Taman Nasional Gunung Halimun Salak. Jurnal of Natural Resources and Environmental Management 9(3): 608-625.

Jongjitvimol T, Boontawon K, Wattanachaiyingcharoen W, Deowanish S. 2005. Nest dispersion of a stingless bee species Apidae, Meliponinae in a mixed deciduous forest in Thailand. The Natural History Journal of Chulalongkorn University 5(2): 69-71.

Kusmana C, Saharjo BH, Sumawinata B, Onrizal, Kato T. 2009. Komposisi jenis dan struktur hutan hujan tropika dataran rendah di Taman Nasional Danau Sentarum, Kalimantan Barat. Jurnal Ilmu Pertanian Indonesia 14(3):149- 157.

Kusmana C, Susanti S. 2015. Komposisi dan struktur tegakan hutan alam di Hutan Pendidikan Gunung Walat, Sukabumi. Jurnal Silvikultur Tropika 5(3):210-217.

Magurran AE. 1988. Ecological Diversity and Its Measurement. London: Croom Helm Limited.

Mawazin, Subiakto A. 2013. Keanekaragaman dan komposisi jenis permudaan alam hutan rawa gambut bekas tebangan di Riau. Indonesian Forest Rehabilitation Journal 1(1): 59-73.

Morisita M. 1959. Measuring of the dispertion of individuals and analysis of the distributional patterns Memories of the Faculty of Science, Kyushu University. Series E (Biology) 2(4): 215235.

Mulyana D. 2015. Suksesi vegetasi dan kualitas tanah ekosistem hutan pegunungan Papandayan pasca gangguan [tesis] Bogor: IPB University.

Odum EP. 1993. Dasar-Dasar Ekologi. Yogyakarta: UGM Pr.

Parinda S. 2011. Perkembangan vegetasi pada areal bekas tebangan dengan sistem silvikultur tebang pilih tanam jalur (TPTJ) (areal IUPHHK PT. Erna Djuliawati, Kalimantan Tengah) [skripsi]. Bogor: IPB University.

Prasetyo D. 2006. Kajian komposisi dan struktur tegakan serta pertumbuhan jenis-jenis komersial, khususnya jenis ramin (Gonystylus bancanus (Miq.) Kurz.) di hutan rawa gambut IUPHHK PT. Diamond Raya Timber, Propinsi Riau. [skripsi]. Bogor: IPB University.

Prasetyo L. 2008. Tutupan lahan TNGHS tahun 19892009 (Land cover at Gunung Halimun Salak National Park 1989-2009). Sukabumi: Gunung Halimun Salak National Park.

Purnama H, Jumani, Biantary MP. 2016. Inventasisasi distribusi tegakan puspa (Schima wallichii Korth) pada berbagai tipe kelerengan di Kebun Raya 
Unmul Samarinda (KRUS) Provinsi Kalimantan Timur. Jurnal Agrifor 15(1): 55-64.

Rani C. 2003. Metode pengukuran dan analisis pola spasial (dispersi) organisme bentik. Jurnal Protein 19(1): 1351-1368.

Sari PN. 2017. Penyebaran dan karakteristik habitat jenis rasamala (Altingia excelsa Noronha) di Taman Nasional Gunung Haimun Salak [skripsi]. Bogor: IPB University.
Setyawan AD. 2000. Tumbuhan epifit pada tegakan pohon Schima wallichii (D.C.) Korth. di Gunung Lawu. Jurnal Biodiversitas 1(1):1420Soerianegara I, A Indrawan. 2005. Ekologi Hutan Indonesia. Bogor: IPB Pr. 